\title{
EFFECTIVENESS OF PEATLAND RESTORATION IMPLEMENTATION IN RIAU PROVINCE
}

\author{
FEBRI YULIANI
}

\author{
FISIP Universitas Riau \\ febby_sasha@yahoo.co.id, febri.yuliani@ lecturer.unri.ac.id
}

\begin{abstract}
The peat phenomenon that occurs in Riau Province negatively impacts the environmental conditions resulting from the management and utilization of peat ecosystem areas that are out of control and irresponsible. For example, forest fires and land that occurred have an impact of smoke haze that hit Riau and Sumatra region. This study aims to analyze the Effectiveness of Peat Restoration in Riau Province. This research is done by using qualitative method. The peatland restoration program that has been established in several districts in Riau Province is also influenced by several factors that influence the implementation process, including the following: (1) Conceptualization of Peatland Restoration Program. Since the restoration program has been rolled out, there are still many parties who do not understand what peatland restoration is. This caused inequality in the implementation of the restoration program. So far, the community considers restoration of peatlands to the extent of government tasks, and for local governments the restoration program is only a pilot project of the central government. In fact, it is wrong, therefore the conceptualization of this restoration must be clear and submitted continuously to the government apparatus, stakeholders and the community. (2) Implementing Institutional Preparedness The readiness of the implementing agency in this case is whether the institutions involved in this peat land restoration program are ready to implement with all the preparations in the form of activity designs, socialization to be performed, supporting funding, and how to respond to society. (3) The Encouragement of Good Local and Formal Figures at Provincial, District, District and Village Levels. In implementing peatland restoration programs, encouragement or support of parties other than those of the relevant official are indispensable, both formal and informal. The conclusions of this study indicate that overall government efforts to implement peat restoration have not been too effective. Some districts have successfully restored their peatlands but in some districts peat restoration has not been an important agenda in the formulation and implementation of policies in the district
\end{abstract}

Keywords: Effectiveness, Policy Implementation, Peat Restoration

\section{Introduction}

Peatlands originally a marginal land, in the development of demand for various uses such as plantations, agriculture and settlement. Peatlands have distinctive characteristics, especially in terms of hydrology. Peat soil is able to store water at 13 times its volume. In practice its use in peat drying for various purposes by making the channels. The drainage practices causing the volume of water stored in the peat soil to be reduced, and become brittle which eventually shrinkage. Shrinkage which continuously makes peatlands decrease (subsidence).

Forest and also peatland a natural resource that provides great benefits for human welfare, either tangible or intangible benefits. Tangible benefits or direct benefits of forest include wood, forest products 
follow-up and others. While the benefits of intangible or indirect benefits of forest among others water regulation, recreation, education, comfort environment and others (Affandi \& Patana in Latifah, 2004: 2).

Peatlands are one of the marginal land types selected primarily by large plantations, as they are relatively rarer and thus the likelihood of land use conflicts is relatively small. Although peatlands have a very strategic function, but because Indonesia is a major producer and consumer of wood commodities, paper and palm oil industries, the transfer of function or reclamation with the drainage of natural peatland in Indonesia is inevitable. The transfer of peatland functions has occurred since the last few decades and is still ongoing until now.

These peat swamp forests are increasingly being logged and replaced by plantation companies with timber and especially oil palm. To produce oil palm, the water level in the swamplands must be lowered through drainage. Due to this drainage, the organic peat soil will dry out, become sensitive to fire and fire.

Indonesia has a peatland area of 20.6 million ha. $43 \%$ is in Sumatra (Wahyunto, et al. 2003). The Sumatra region which has peatland is Meranti Regency which consists of 3 (three) large islands: the island of Pedang, Tebingtinggi Island, and Rangsang Island. Meranti Islands Regency Region based on the PIPIB map, almost all of the area is peatland. Based on these facts, caution is needed in using the land so as not to cause problems. There are several factors that cause peatlands to be considered at this time to have meaning and important role is (1) Increasing demand and demand for water; (2) Increasing poverty of communities around peatland forests; (3) Increased influence of globalization; and (4) climate change (Daryono, 2009). Increased water demand, especially for agricultural and plantation needs. But problems will arise on peatlands when drainage is done by making canals. The purpose of this channel is to reduce the water saturation conditions in the root layer of plants. As a result the peatland becomes dry and no longer holds water which then results in subsidence or collapses. There is something to be understood about peatlands, that one of the characteristics of peatlands is irreversible drying or non rewetable. When peatlands experience a degree of drought, peat cannot be wetted again (Widyati, 2011).

Globally, Indonesia's peatlands occupy the fourth position as the largest peatland in the world after Canada, Russia and the United States. Indonesia has a peat land area of 20 million ha, Canada 170 million ha, Russia 150 million ha, and the United States 40 million ha (Agus and Subiksa, 2008). Southeast Asia is the largest tropical peatland owner in the world with an area of $56 \%$ of the world's total tropical peatlands. Indonesia alone accounts for $47 \%$ of the world's tropical peatlands, making it the largest peatland country in Southeast Asia.

Peatlands have an important role in maintaining and maintaining the balance of the living environment both as a reservoir of water and carbon storage. In addition peat is the owner of endemic and distinctive biodiversity. This characteristic is influenced by the characteristics of peatland which is a unique ecosystem with acidic $\mathrm{pH}$, poor in nutrients, and contains thick organic material and is always submerged in water. This specialty only supports.

\section{Theoretical Background}

Peat is formed from the accumulation of crop residues, both decayed and not. The accumulation is thicker because the decomposition process is hampered by conditions of lack of oxygen and / or other environmental conditions that cause pressure on the decomposers. Therefore, peatlands are commonly found in backswamp areas or drainage areas where drainage is poor. The formation of peat soil is a geogenic process, namely the formation of soil caused by the process of deposition and transportation, in contrast to the process of forming mineral soil which is generally a pedogenic process (Hardjowigeno, 
1986). Several studies have estimated the formation of peat in the world between $10,000-5,000$ years ago (in the Holocene period) and peat in Indonesia occurred between 6,800-4,200 years ago (Andriesse, 1994). Based on the search for peat age using radio isotope (carbon dating) techniques, the age of peat in Central Kalimantan is even older, which is formed around 6,230 years ago at a depth of $100 \mathrm{~cm}$ to 8,260 years at a depth of $5 \mathrm{~m}$ (Siefermann et al. 1987). From one location in Central Kalimantan, Page et al. (2002) shows the distribution of peat age, which illustrates that the formation of peat requires a very long time. Peat grows at a rate between $0-3 \mathrm{~mm} /$ year. Indonesia's peatlands are found in lowland and highlands. In general, peat swamp land in the lowlands is found in the tidal swamp area and the swamp swamp, located between two major rivers in physiography / landform swamps behind the river (backswamp), swalle swamps, closed basin, and coastal plain (coastal plain). Highland peat swamp land is commonly found in basin as contained in Rawa Pening (Central Java), Padang Sidempuan (North Sumatra), and Danau Sentarum, Kapuas Hulu (West Kalimantan). Most peat swamp land is in the lowlands and only a small portion is found in the highlands.

\section{Metodology}

This research type is qualitative with explorative method This research activity will use two data source, that is primary data that is data obtained directly from field, and secondary data that is data obtained through study of documents from various sources relevant in this activity. Primary data will be obtained through Focus Group Discussion (FGD) in research areas, Observation on perceptions and behaviors, and interviews using questionnaires. The secondary data of this study are research reports, journals, annual reports, evaluation reports, regulatory and legislative documents, minutes of meetings and other relevant documents.

\section{Result and Discussion}

In addition to its vital ecological role, the position of some of Indonesia's peatlands, especially in Riau, also has a strategic role in the context of national defense and defense. The strategic role of peatlands is mainly in the Meranti Islands (Riau) Regency which borders the sea with Singapore and Malaysia in the Malacca Strait. As the spearhead and marker of state borders, the Meranti Islands peatlands play an important and strategic role in social and economic defense.

Government and communities in Meranti Islands have successfully restored peatlands by involving communities through sago plantation programs on peatlands and have important economic impacts. The government and the people of Meranti have inspired how to protect the Meranti Islands as a peat area and at the same time as the leading island of Indonesia by prioritizing sustainable ecological and socio-economic defense as another form of defense of sovereignty in addition to defense with a militaristic and legalistic approach.

In general, the ecological defenses and carrying capacity in Indonesia's peatlands face serious and complicated challenges only due to climate change conditions such as El Nino and an increasingly erratic and irregular rainy and rainy season. This is certainly exacerbated by the cultivation of agriculture and massive industrial scale monoculture plantations, exploitative, and full of canals which consequently are vulnerable to drought.

The damage to the ecology of peatlands in Indonesia in general has been caused by two main activities: open drainage and land fires. Changes to the nature of peatlands create great ecological losses. Utilization that ignores the nature of peatlands will make peat dry. Utilization that ignores the nature of peatlands will make peat dry and very flammable. 


\section{Socio-Economic Conditions of the Peat Area}

Though endowed with vast resources, socio-economic conditions in Indonesia's peatlands generally represent the "resource curse" picture often used by development and ecological anthropologists. What is meant by "resource curse" is a concept that explains why countries rich in natural resources such as Indonesia often grow to become poor precisely when they are so busy serving the interests of world market commodities from the timber era 1980-2005 to the present oil palm plantations from 2005 to now (Van Klinken, 2008; Rosser, 2007; Ross, 2003).

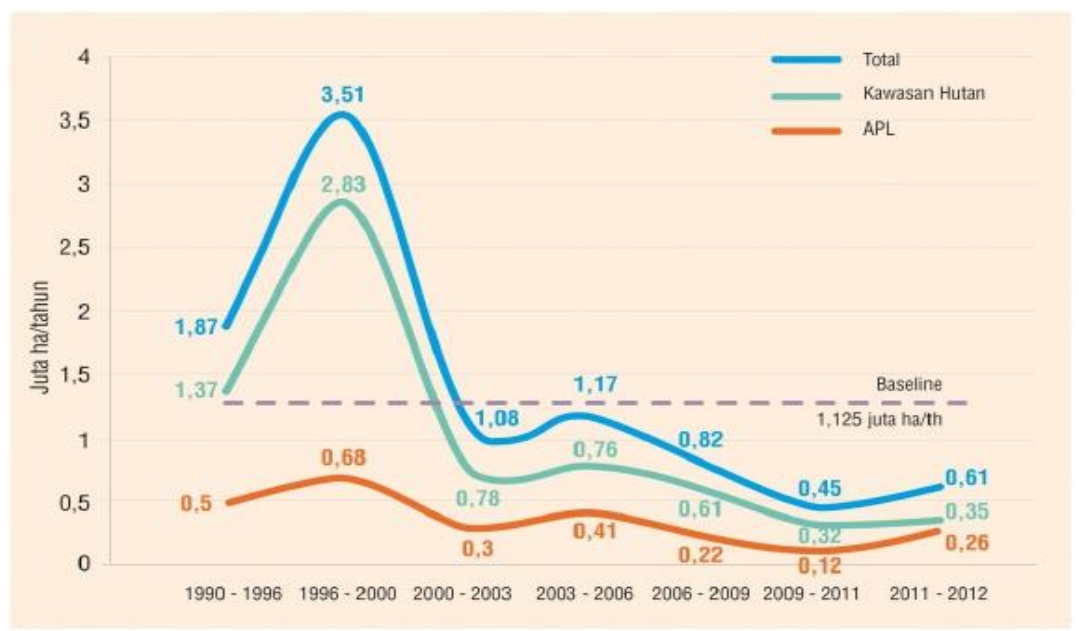

Chart 1. Deforestation 1990 -2012 (KLHK, 2012)

The general condition of the management of peat areas in Riau illustrates the lack of understanding, knowledge and utilization. This picture mainly occurs in terms of lack of knowledge about the peculiarities, complexity, and vulnerability of the peat ecosystem and the natural linkages between peat, biodiversity, carbon, and water. Vegetation restoration is needed in order to restore the vegetation cover of the peat ecosystem so that it resembles the structure and function of the peat ecosystem as the original. For example in Riau Province alone, from 1982 to 2007 it has been converted to 1.83 million hectares or $57 \%$ of the total area of peat. In 2009 , the Indonesian government policy again converted 2 million hectares of peatland to oil palm plantations. The rate of conversion of peat increases rapidly, while for non-peat land the increase is relatively slow (WWF, 2008).

Indonesia's peat fires, especially in Riau, contribute the largest carbon emissions to the atmosphere and provide alarming social and ecological impacts (Miettinen and Liew, 2010). The alarming conditions in the peat ecosystem occur due to lack of understanding and data and the increasing need for land, resulting in Indonesia's peatlands, especially in Riau being a massive and intensive object for agricultural and plantation areas with the use and transfer of large-scale land to serve the needs of industry and markets especially in this decade. Peatland management that relies more on short-term economic values will tend to favor capital owners, and easily marginalize community rights and those whose livelihood conditions depend heavily on the healthy ecological functions of peatlands for meeting sustainable needs.

The history of peat land use for agriculture in Riau is quite long. The history of peatland utilization for agriculture in Riau is quite long. The use of peat for agriculture begins with the success of indigenous people in farming on peat land for the needs of food, fruits and other commodities. A number of best practices in the community about how to develop cultivation on peatlands in a sustainable manner have long been known. Traditional paludicular systems are intended to keep peatlands in their original 
character by planting the typical vegetation of peat / endemic swamps, or vegetation that remains productive in wetland conditions. Paludicultural products can provide commodities that include food, feed, fiber and fuel, as well as industrial raw materials. However, the pattern of cultivation by applying the model of paludikultur that relies on local people (people farming) in fact increasingly lagging behind by agricultural models or large-scale plantations (corporate farming). Until the past decade peatlands have been managed more by large-scale companies that carry out timber and oil palm plantations (Dedi Nursyamsi, et.al, Springer, 2016). Socio-economic studies that address aspects of sustainability and ecological services on peatlands illustrate the situation that almost all Indonesian peatlands have been exploited in such a way for commercial plantation and cultivation activities (Kobayashi and Segah, 2016).

Peatlands have an economic function, except that peatland management needs to be done wisely and carefully because the peat ecosystem is an fragile ecosystem, so that if management is not done properly, the forests and peatlands will not be sustainable. Unwise management of peat areas has also resulted in land conflicts. Problems of land conflicts in peat areas occur mainly because of unclear forest and plantation area boundaries and lack of land tenure. In a number of studies, land conflicts in peatland areas did not occur when land management involved the community (M. Osaki et al, Springer, 2016)

Table 1. Location of Peatlands and Poverty Rate

\begin{tabular}{|c|c|c|c|c|}
\hline \multirow[t]{2}{*}{ Island location } & \multirow{2}{*}{$\begin{array}{l}\text { Peat Area } \\
(\mathrm{Ha})\end{array}$} & \multicolumn{2}{|c|}{ Number of Regencies } & \multirow{2}{*}{$\begin{array}{c}\text { Number of } \\
\text { Villages in Peat } \\
\text { Area }\end{array}$} \\
\hline & & $\begin{array}{l}\text { Poverty > Average } \\
\text { Poverty National }\end{array}$ & $\begin{array}{c}\text { Poverty < Average } \\
\text { National }\end{array}$ & \\
\hline Sumatera & $5,965,220$ & 16 & 25 & 5.011 \\
\hline Kalimantan & $5,036,164$ & 2 & 25 & 2.990 \\
\hline Papua & $4,931,054$ & 20 & - & 2.464 \\
\hline Indonesia (total) & $15,932,438$ & 38 & 50 & 10.465 \\
\hline $\begin{array}{l}\text { Source: } \\
\text { 1. Peat area da } \\
\text { Agriculture } \\
\text { 2. Data on the } \\
\text { Affairs PM } \\
\text { 3. If the peatla } \\
\text { Kalimantan } \\
\text { (Agus and }\end{array}$ & $\begin{array}{l}\text { Indonesian } M \\
\text { 16) } \\
\text { ber of distric } \\
010 \text { ) } \\
\text { are in Aceh p } \\
\text { ulated then th } \\
\text { ksa, 2008) }\end{array}$ & $\begin{array}{l}\text { histry of Environment } \\
\text { and village jumlas } \\
\text { ovince, North Sumatr } \\
\text { total area of Indones }\end{array}$ & $\begin{array}{l}\text { and Forestry and M } \\
\text { rocessed from the } \\
\text {, West Sumatra, Be } \\
\text { ia's peatlands about }\end{array}$ & $\begin{array}{l}\text { istry of } \\
\text { inistry of Home } \\
\text { gkulu and East } \\
1 \text { million ha }\end{array}$ \\
\hline
\end{tabular}

Expansive development based on exploitation of natural resources drives teturial conflict. The local people's lives are urged, lack of recognition of rights and unequal access to resources. Biases of interest in the allocation of natural resources and permits lead to the emergence of prolonged and escalating conflicts. Peat ecosystem areas are synonymous with nutrient-poor soils and are flooded every year, often forcing the surrounding communities, who are not accustomed to or not yet supported by the Government to implement appropriate cultivation, tend to maintain their lives just by hunting, fishing, and cutting down timber (illegal logging). or the current conditions, illegal logging activities are reduced due to the exhausted commercial trees around the peat area.

In addition, the reduction of illegal logging is also caused by the increasing awareness of the community, as a result of extension activities and guidance that has been done by various parties and from the impact they have felt directly, either in the form of the shrinking of forest products and natural disasters that befall those that cause the condition of society in peat areas it is relatively poor and backward. 
The policy of conversion of peatland for large-scale settlement and rice field activities was once carried out by the Government of Indonesia through the Million Hectares Peatlands project ". The project was finally stopped because it proved to have enormous environmental damage. Initially the program in the era of President Soeharto was aimed at securing national food, but in its implementation is considered failed because it raises various problems both technical, social, economic, cultural and ecological environment.

In addition to the unwise conversion of peatlands, land clearing activities using fire became the main cause of the 1997 peat fires and smoke pollution in Central Kalimantan (Rieley, et.al. 2002). Then the construction of canals for irrigation has led to excessive peat drainage during the dry season. Peat swamp ecosystems are damaged and experience a decrease in water level due to drainage channels that are not taken into account and result in drought, and vice versa in the rainy season resulting in flooding.

Through Presidential Regulation No. 1 of 2016 the Central Government established a Peat Restoration Agency. This Presidential Regulation regulating the management of peatlands with peatland restoration is one of them by building a canal block (Canal Blocking). Canal blocking is a national agenda for peat restoration with the main objective of addressing land fires due to the destruction of peat ecosystems. Preventing peatland fires by keeping peat soil wet is considered a wiser move than a timeconsuming handling.

The implementation of efforts to restore damaged peat ecosystems is the responsibility of the government cq. BRG. This was stated in the Presidential Regulation of the Republic of Indonesia Number 1 of 2016 concerning the Peat Restoration Agency. In carrying out efforts to restore the function of the peat ecosystem to prevent the recurrence of forest and land fires

and the impact of smoke, BRG has the task of facilitating and coordinating peat ecosystem restoration covering an area of 2 (two) million hectares. Presidential Regulation no. 1 of 2016 mandates that in carrying out its duties and functions, the Peat Restoration Agency is supported by organizational equipment consisting of: (1) the Body Secretariat; (2) Deputy for Planning and Cooperation; (3) Deputy for Construction and Maintenance Construction; (4) Deputy for Education, Socialization, Participation and Partnership; (5) Deputy for Research and Development. Based on BRG's internal and external strategic issues, BRG's strategic environment can be mapped according to existing strengths, weaknesses, opportunities and threats. From the results of the analysis, it was concluded that BRG's strategic objectives include covering protected areas and cultivation areas in hydrological unity of peat so as to be managed sustainably to support the improvement of people's welfare and the quality of human life and the environment.

The Peat Restoration Agency is tasked with achieving three restoration objectives, namely: (1) recovery of hydrology, vegetation and socio-economic carrying capacity of degraded peat ecosystems; (2) protection of peat ecosystems for life support; (3) rearrangement of sustainable management of [the exploitation of] peat ecosystems. From this task, the object managed by BRG is the Peat Hydrological Unity (KHG).

Peat ecosystem management aims to achieve multi-benefits, namely economic, social and ecological benefits. Referring to this goal, the formulation of the program which is the responsibility of BRG is the Facilitation and Coordination Program for Peat Restoration in 7 Provinces. The goal to be achieved from the implementation of the program is to accelerate the recovery of peat ecosystems in 7 provinces to provide sustainable use for economic, social and ecological interests.

Efforts to achieve program objectives, as well as the achievement of program performance indicators are carried out through five activities. Each activity describes the implementation of the duties and functions of each deputy in the scope of BRG.

Activities within the scope of BRG Program consist of: (1) Activity of the Secretary of the Agency in support of administrative, operational and financial management facilities; (2) Activities of Deputy for Planning and Cooperation; (3) Activities of Deputy for Construction, Operation and 
Maintenance; (4) Activities of Deputy for Education, Socialization, Participation and Partnership; (5) Activities of Deputy for Research and Development.

Indicatively, the funding requirement for the implementation of the Coordination and Facilitation Program for Peat Ecosystem Restoration in 7 Provinces in 2016-2020 is Rp. 10,593,000,000,000 (ten trillion five hundred ninety three billion rupiahs). The amount of funding is only limited to the financing needs of achieving work targets.

The apparatus shopping needs (office services and operations) during 2016-2020 are projected to be Rp. 298,000,000,000 (two hundred ninety eight billion rupiahs). To further optimize the achievement of BRG's performance targets and targets, it still needs to be supported by involving the role of all parties including building cooperation with overseas development partners and the participation of the business sector and civil society groups.

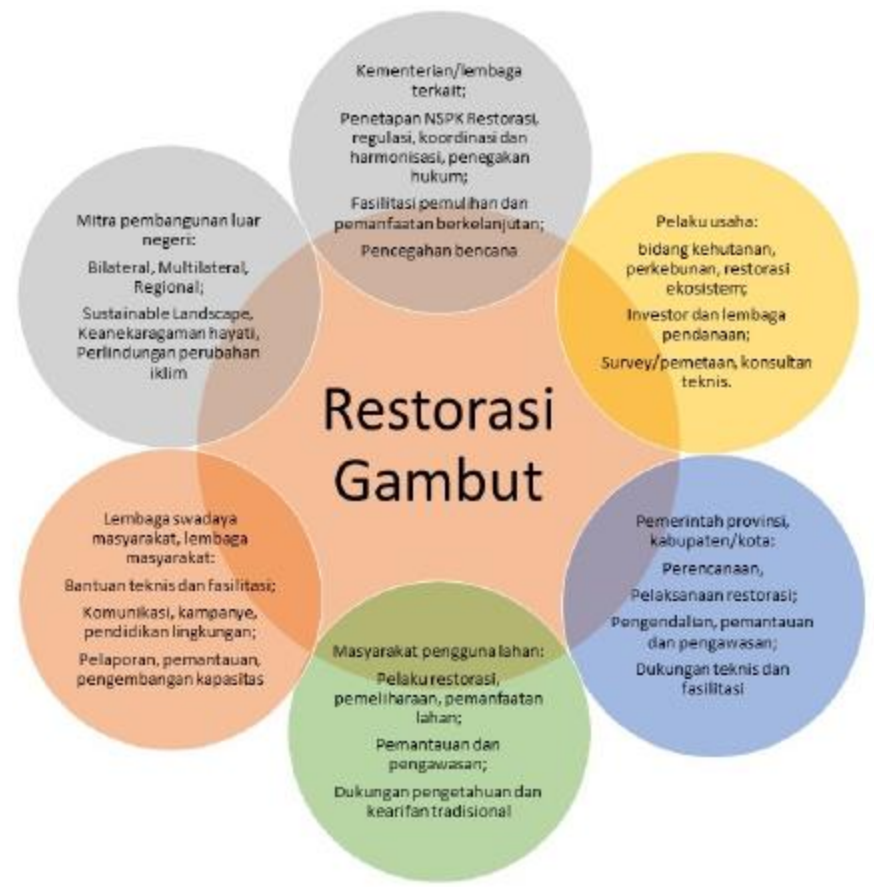

Picture 1. BRG Stakeholder Role

However, from all the above efforts, the core of the mandate, task and function of BRG is to implement peat restoration to support the preservation of natural resources, the environment and disaster management, and governance. With the re-functioning of KHG through restoration interventions, the peat ecosystem will be able to provide habitat for its biodiversity, and able to prevent flooding in the rainy season and prevent fires.

\section{Conclusion}

Based on the results of the explanation of the results and discussion, the effectiveness of peat restoration must refer to: (1) the direction of national policy, through the National Development Goals The Leading Sector includes Sustainable Development through (a) Maintaining the environmental quality of the peat ecosystem to improve the environmental carrying capacity, water security and public health. (b) Developing a very lagging village which is a peat village through utilizing the potential of forest resources and forest environment in a sustainable manner to improve the economy and prosperity 
of a sustainable society. (2). Direction of BRG Policies and Strategies, BRG Policy in order to carry out the duties and functions to carry out national development policy directions and national priority programs in coordinating and facilitating the restoration of peatlands in 7 (seven) provinces, namely Riau, Jambi, South Sumatra, West Kalimantan, Central Kalimantan, South Kalimantan, and Papua. (3). The institutional framework, in the need for peatland restoration implementing organizations at the site level, must be strengthened by involving regional institutions at the provincial level in charge of facilitating the planning, supervision and technical guidance on the implementation of peat restoration. The institution includes several related regional work units (SKPD), technical implementation units (UPT) and related vertical agencies, and LSM

\section{Recommendation}

1. The need for regulation that allows ex-cultivation areas included in protected peatland to be managed through investment schemes including ecosystem restoration concessions or managed as areas of local community wisdom and arrangements for the formulation and protection of types of biodiversity in peat ecosystems.

2. Regulations that provide incentives for concession holders who voluntarily change their concession areas from cultivation areas to protected peatlands managed by the concession holders and prioritize the integration of KHG zoning and peatland rural areas into district and / or provincial spatial plans.

3. There needs to be a reward or award in the form of fiscal transfers to regions that have successfully implemented the protection and management of peat ecosystems.

4. Clear coordination between stakeholders of peat restoration especially at district government

\section{Referensi}

Agus, F. dan I.G. M. Subiksa. 2008. Lahan Gambut: Potensi untuk Pertanian dan Aspek Lingk ungan. Balai Penelitian Tanah dan World Agroforestry Centre (ICRAF), Bogor, Indonesia.

Andriesse, J.P. 1994. Constrainsts and opportunities for alternative use options of tropical peat 1 and. In B.Y. Aminuddin (Ed.). Tropical Peat; Proceedings of International Symposium on Tropi cal Peatland, 6-10 MAY 1991, Kuching, Serawak, Malaysia.

\section{Badan Restorasi Gambut R.I. 2016. Rencana Strategis BRG 2016-2020. Jakarta}

Daryono, H. (2009). Potensi, permasalahan dan kebijakan yang diperlukan dalam pengelolaan hutan dan lahan rawa gambut secara lestari. Jurnal Analisis Kebijakan Kehutanan, 6 (2).

Kementerian Lingkungan Hidup dan Kehutanan R.I. 2012. Indeks Lingkungan Hidup Indonesia. Jakarta

Klinken, G. Van (2008). Blood, timber, and the state in West Kalimantan, Indonesia, Asia Pacifi c viewpoint, 49, pp. 35-47

Latifah, Siti. 2004. Penilainan Ekonomi Hasil Hutan Non Kayu. http://library.usu.ac.id/downlo ad/fp/hutan-siti7.pdf. Diakses pada tanggal 15 Mei 2016 pada pukul 19.15 wib. 
Miettinen, J., and Liew, S.C., 2010, Status of Peatland Degradation and Development in Sumatra and Kalimantan, Ambio, vol. 39, no. 5/6, pp. 394- 401.

Mitsuru Osaki, Dedi Nursyamsi, Muhammad Noor, Segah, H. (2016). Peatland in Indonesia in Osaki, M and Tsuji, N. (2016, Eds. ). Tropical Peatland Ecosystems, pp.49-58. Springer, Tokyo.

Page, S.E., Siegert, F., Rieley, J.O., Boehm, H-D.V., Jaya, A., Limin, S.H. 2002. The amount of carbon released from peat and forest $i$ res in Indonesia during 1997, Nature, 420, 61-65.

Sieffermann, G., Triutomo, S., Sadelman, M.T., Kristijono, A. and Parhadimulyo, S.A., 1987: The pe at genesis in the lowlands of Central Kalimantan provinc, The respective influence of podzolisation and bad drainage, the two main processes of peat genesis in Kalimantan, In ternational Peat Congress, Yogyakarta, ORSTOM, Yogyakarta: 17 p.

Widyati, E. (2011). Kajian Optimasi Pengelolaan Lahan Gambut dan Isu Perubahan Iklim. Jurnal Tekno Hutan Tanaman, 4(2), 57-58.

WWF. 2008. Deforestation, forest degradation, biodiversity loss and CO2 emissions in Riau, Sumatra, Indonesia. WWF Indonesia Technical Report. www.wwf.or.id 